\title{
Factors affecting milk yield at peak and during current lactation of Holstein cows*
}

\author{
K.O. Coelho' ${ }^{1}$, P.F. Machado ${ }^{2}$, A. Coldebella ${ }^{3}$, P.M. Meyer ${ }^{4}$ \\ L.D. Cassoli ${ }^{2}$ and P.H.M. Rodrigues ${ }^{5}$ \\ ${ }^{1}$ Veterinary College, Federal University of Goias/UFG, Brazil \\ ${ }^{2}$ Agricultural College "Luiz de Queiroz", University of Sao Paulo/USP, Brazil \\ ${ }^{3}$ Brazilian Centre of Agriculture and Animal Research/EMBRAPA - Suinos e Aves, Brazil \\ ${ }^{4}$ Brazilian Institute of Geography and Statistics/IBGE, Brazil \\ ${ }^{5}$ Veterinary Medicine and Animal Science College, University of Sao Paulo/USP, Brazil
}

\begin{abstract}
With the objective of investigating the impact of events occurring pre and postpartum on milk yield at peak and during lactation, data were collected from 1.042 lactations of 665 Holstein cows. Body condition score (BCS), calving season (CS), dry period length (DPL), occurrence of diseases and milk yield were registered. Calving season (summer), DPL, BCS at drying off, first somatic cells count (SCC) after calving, occurrence of retained placenta and of displaced abomasum negatively affected milk yield at peak. The same events, excluding CS, and including occurrence of clinical mastitis until 60 days post-partum, negatively affected milk yield during lactation.
\end{abstract}

KEY WORDS: dairy cow, disease, milk production, somatic cells count

\section{INTRODUCTION}

Despite the low milk productivity in Brazil, improvements characterized by pasture fertilization, introduction of specialized animals and use of genetic improvement techniques have been occurring. However, milk producers are still not well-capacitated or organized, resulting in lack of knowledge about animal well-fare, causing high occurrence of diseases, and, consequently, low milk yield. Some research has been accomplished aiming to identify critical points, considering dairy herd productivity. Inadequate nutrition (Ruegg and Milton, 1995), heat stress (Gasparino, 1996), occurrence of infectious or metabolic

\footnotetext{
* Supported by CNPq and FAPESP, Brazil

${ }^{4}$ Corresponding author: e-mail: paulameyer@ibge.gov.br
} 
diseases (Fleisher et al., 2001) and calving season (Gasparino, 1996) have been associated with decrease in milk yield. Therefore, this study aimed to evaluate the impact of events occurred pre- and postpartum on milk yield at peak and during lactation (305 days).

\section{MATERIAL AND METHODS}

In the study, observations from 1.042 lactations were used, from 665 Holstein cows of a commercial herd (Brazil). Animals were confined, fed 8 times/day and milked in milking parlour. They received a TMR (48\% roughage on dry matter basis), with the following composition, \%: DM 50.2, CP 16.9, NDF 31.4, nonstructural carbohydrate of DM 40.2, and $1.75 \mathrm{Mcal} / \mathrm{kg}$ DM of net energy for lactation. Calving season, dry period length and milk yields (at peak and during lactation) were registered. Diseases (ketosis, displaced abomasum, milk fever, clinical mastitis, sub-clinical mastitis, metritis, pneumonia, retained placenta and lameness) were registered as occurrence $(=1)$ or non-occurrence $(=0)$ considering only the first occurrence. Body condition score (BCS) at drying off and at calving were registered by using a scale from 1 (thin) to 5 (obese) (Wildman et al., 1982).

Multiple regression was used to determine factors responsible for changes in milk yield at peak and during lactation (305 days) (SAS, 1999). For milk yield at peak, the following variables were considered: calving season, BCS at drying off and at calving, length of dry period, peripartum diseases (pneumonia until 60 days, lameness until 60 days, clinical mastitis until 60 days, natural logarithm of the first SCC (LSCC), milk fever, displaced abomasum, metritis, retained placenta and ketosis). For milk yield during lactation (305 days), in addition to the variables cited above, other parameters were taken into account: diseases during lactation (pneumonia, lameness, clinical mastitis and sub-clinical mastitis during lactation). For all analyses, interaction among parity and individual factors was verified, due to heterogeneity of variance among animals of $1^{\text {st }}, 2^{\text {nd }}$ and $3^{\text {rd }}$ or higher lactation.

\section{RESULTS AND DISCUSSION}

\section{Milk yield at peak of lactation}

Approximately $43 \%\left(\mathrm{R}^{2}=0.427\right)$ of the factors responsible for changes in milk yield at peak were identified in this study. Animals that calved during summer produced less milk at peak than the ones that calved in the wintertime. Animals in $2^{\text {nd }}$ lactation $(\mathrm{P}<0.0001)$ were more affected by the heat stress than in third or higher lactation $(\mathrm{P}=0.0174)$. However, primiparous cows were not influenced by calving season $(\mathrm{P}=0.2040)$.

Considering BCS at calving, each increase of one unit of BCS above 3.5 represented an increase in milk at peak of $1.6 \mathrm{~kg}$. There was no effect of parity on 
this variable. The BCS at drying off influenced negatively milk yield at peak. Each increase of one unit of BCS (above 3.5) at drying off represented 3.41 and $3.66 \mathrm{~kg}$ lower milk yield at peak $(\mathrm{P}<0.0001)$ for animals in $1^{\text {st }}$ and $3^{\text {rd }}$ lactation, respectively. Milk yield of $2^{\text {nd }}$ lactation animals was not affected.

Dry period length presented a quadratic effect, i.e. milk yield at peak increased until 100 days of dry period and then decreased, representing losses of approximately $0.0007 \mathrm{~kg}$ of milk/day.

For each unitary increase in LSCC, milk yield at peak was 1.71 and $1.30 \mathrm{~kg}$ lower for animals in $2^{\text {nd }}(\mathrm{P}<0.0001)$ and $3^{\text {rd }}$ or higher $(\mathrm{P}=0.0004)$ lactation, respectively. Primiparous cows were not affected $(\mathrm{P}=0.5297)$.

Occurrence of retained placenta caused a decrease in milk yield at peak of 4.3 $(\mathrm{P}<0.0001)$ and $2.8 \mathrm{~kg}(\mathrm{P}=0.0222)$ for $2^{\text {nd }}$ and $3^{\text {rd }}$ or higher lactation, respectively. But this parameter had no influence on primiparous cows $(\mathrm{P}=0.5297)$. Displaced abomasum also decreased milk yield at peak by $2.90 \mathrm{~kg}(\mathrm{P}=0.0159)$ independent of lactation number. Occurrence of ketosis $(\mathrm{P}<0.0001)$ showed a positive effect independent of lactation number. It is possible to conclude that high production animals are more susceptible to this disorder.

\section{Milk yield during lactation (305 days)}

Approximately $25 \%\left(\mathrm{R}^{2}=0.244\right)$ of changes in milk yield during lactation $(305$ days) were due to factors identified by the model. The BCS at calving showed a positive effect on milk yield during lactation. For each increase of one unit of BCS (above 3.5) at calving, milk yield was increased by $462.7 \mathrm{~kg}(\mathrm{P}<0.0001)$ during lactation. These results are similar to those observed by Ruegg and Milton (1995), where cows with higher body reserves at calving produced more milk. For each increase of one BCS unit (above 3.5) at drying off, cows produced 733.1 $(\mathrm{P}<0.0001), 399.6(\mathrm{P}=0.0152)$ and $1.090 .3 \mathrm{~kg}(\mathrm{P}<0.0001)$ less milk during lactation in $1^{\text {st }}, 2^{\text {nd }}$ and $3^{\text {rd }}$ or higher parity, respectively.

Dry period length showed a quadratic effect, i.e. until 100 days of dry period there was an increase in milk yield and then a reduction from that point of approximately $0.3 \mathrm{~kg}$ milk/day. Length of the dry period is very important to maximize milk yield. Animals dried off close to calving have no time to restore secretory cells, influencing milk yield in the subsequent lactation (Sorensen and Enevoldsen, 1991).

Retained placenta caused a decrease of 992.1 and $501.1 \mathrm{~kg}$ milk for animals in $2^{\text {nd }}$ $(\mathrm{P}<0.0001)$ and $3^{\text {rd }}$ lactation $(\mathrm{P}=0.0972)$, respectively. Cows displaced abomasum postpartum produced $682.9 \mathrm{~kg}(\mathrm{P}=0.0183)$ less milk during lactation, independent of lactation number.

Milk yield during lactation was influenced by LSCC. For each unitary increase of LSCC, milk yield decreased $416.6(\mathrm{P}<0.0001)$ and $227.8 \mathrm{~kg}(\mathrm{P}=0.0097)$ for animals of $2^{\text {nd }}$ and $3^{\text {rd }}$ lactation, respectively. However, LSCC did not affect milk yield during lactation in primiparous cows. Occurrence of clinical mastitis until 60 days after 
calving also decreased milk yield during lactation, independent of lactation number $(\mathrm{P}=0.0498)$. It resulted in a reduction in milk yield of $269.2 \mathrm{~kg}(2.9 \%)$ during lactation. It was also observed that cows with high SCC during lactation had higher milk yield. It is important to emphasize that this last effect was only observed in animals in $2^{\text {nd }}$ and $3^{\text {rd }}$ lactation $(\mathrm{P}<0.0001)$.

\section{CONCLUSIONS}

Milk yield at peak was negatively affected by: calving season, BCS at drying off, dry period length, first SCC as well as occurrence of retained placenta and displaced abomasum. The same events, excluding calving season and including occurrence of clinical mastitis, negatively affected milk yield during the entire lactation.

\section{REFERENCES}

Fleisher P., Hoedemarker M., Metzner M., 2001. Clinical disorders in Holstein cows: Incidence and association among lactation risk factors. Acta Vet. 70, 157-165

Gasparino E., 1996. Estudo de fatores genéticos e de meio que influenciam o desempenho de vacas mestiças à primeira cria. Viçosa, Dissertation - Universidade Federal de Viçosa, pp. 112

Ruegg P.L., Milton R.L., 1995. Body condition scores of Holstein cows on Prince Edward Island, Canada: relationships with yield, reproductive performance, and disease. J. Dairy Sci. 78, 552564

Sas Institute, 1999. SAS/STAT User's Guide 8.0. Sas Institute Inc., Cary (CD-ROM)

Sorensen J.T., Enevoldsen C., 1991. Effect of dry period length on milk production in subsequent lactation. J. Dairy Sci. 74, 1277-1283

Wildman E.E., Jones G.M., Wagner P.E., 1982. A dairy cow body condition scoring system and its relationship to select production characteristics. J. Dairy Sci. 65, 495-501 